\title{
An environmental scan of academic pediatric emergency medicine at Canadian medical schools: Identifying variability across Canada
}

\author{
Jennifer D. Artz, PhD*; Garth Meckler, $\mathrm{MD}^{\dagger}$; Niran Argintaru, MD; Roderick Lim, MD ; \\ Ian G. Stiell, MD, MSc ${ }^{\text {III }}$
}

\section{ABSTRACT}

Objective: To complement our environmental scan of academic emergency medicine departments, we conducted a similar environmental scan of the academic pediatric emergency medicine programs offered by the Canadian medical schools.

Methods: We developed an 88-question form, which was distributed to pediatric academic leaders at each medical school. The responses were validated via email to ensure that the questions were answered completely and consistently.

Results: Fourteen of the 17 Canadian medical schools have some type of pediatric emergency medicine academic program. None of the pediatric emergency medicine units have full departmental status, while nine are divisions, two are sections, and three have no status. Canadian academic pediatric emergency medicine is practised at 13 major teaching hospitals and one specialized pediatric emergency department. There are 394 pediatric emergency medicine faculty members, including 13 full professors and 64 associate professors. Eight sites regularly take pediatric undergraduate clinical clerks, and all 14 provide resident education. Fellowship training is offered at 10 sites, with five offering advanced pediatric emergency medicine fellowship training. Half of the sites have at least one physician with a Master's degree in education, totalling 18 faculty members across Canada. There are 31 clinical researchers with salary support at nine universities. Eleven sites have published peerreviewed papers $(n=423)$ in the past five years, ranging from two to 102 per site. Annual academic budgets range from $\$ 10,000$ to $\$ 2,607,515$.

Conclusions: This comprehensive review of academic activities in pediatric emergency medicine across Canada identifies the variability across the country, including the recognition of sites above and below the national average, which may prompt change at individual sites. Sharing these academic practices may inspire sites to provide more support to teachers, educators, and researchers.

\section{RÉSUMÉ}

Objectif: Afin de compléter l'analyse environnementale des départements universitaires de médecine d'urgence, nous avons procédé au même type d'analyse que la précédente mais, cette fois, pour les programmes universitaires de médecine d'urgence pédiatrique (MUP), offerts par les écoles de médecine au Canada.

Méthode: Nous avons élaboré un formulaire comptant 88 questions, qui a été distribué aux responsables de l'enseignement de la médecine d'urgence pédiatrique dans chacune des écoles de médecine. Les réponses ont été validées par courriel afin de nous assurer de leur cohérence et de leur caractère complet.

Résultats: Sur les 17 écoles de médecine au Canada, 14 offrent une forme quelconque de programme universitaire de MUP. Toutefois, aucune des unités de MUP ne jouit du titre de département à part entière; ainsi, neuf unités sont reconnues comme des divisions et deux, comme des sections, tandis que trois n'ont aucun titre officiel. La MUP universitaire se pratique dans treize grands hôpitaux d'enseignement et dans un service spécialisé en MUP. Le corps enseignant compte 394 membres en MUP, dont 13 professeurs titulaires et 64 professeurs agrégés. Dans huit universités, on accepte normalement les stagiaires cliniques de premier cycle en pédiatrie, et les quatorze écoles offrent de la formation au niveau de la résidence. Une formation postdoctorale est donnée dans dix écoles, et cinq d'entre elles fournit une formation spécialisée en MUP. On compte au moins un médecin ayant une maîtrise en éducation dans la moitié des établissements, ce qui porte à 18 leur nombre total au Canada. Trente et un cliniciens-chercheurs reçoivent une aide salariale dans neuf universités. Des articles évalués par les pairs $(n=423)$ ont été publiés dans onze écoles au cours des cinq dernières années, et le nombre varie de 2 à 102 dans chacune d'elles. Enfin, les budgets annuels consacrés à l'enseignement de la MUP varient de 10000 \$à 2607515 \$.

From the *The Ottawa Hospital, Ottawa, ON; †BC Children's Hospital, University of British Columbia, Vancouver, BC; $¥$ Department of Emergency Medicine, University of Toronto, Toronto, ON; §Department of Paediatric Emergency Medicine, London Health Sciences Center, London, ON; IDepartment of Emergency Medicine, University of Ottawa, Ottawa, ON; and the ॥Clinical Epidemiology Program, Ottawa Hospital Research Institute, Ottawa, ON.

Correspondence to: Dr. Ian Stiell, Department of Emergency Medicine, 1053 Carling Avenue, Room F657, University of Ottawa, Ottawa, ON K1Y 4E9, Canada; Email: istiell@ohri.ca 
Conclusion: Cet examen complet des activités universitaires en MUP, mené à la grandeur du pays fait ressortir des différences entre les écoles de médecine au Canada, notamment le classement de celles qui se situent au-dessus ou audessous de la moyenne nationale, ce qui peut susciter des changements au sein des écoles elles-mêmes. Ainsi, le fait de porter à la connaissance des autres les pratiques universitaires peut inciter les écoles à donner plus de soutien aux enseignants, aux médecins-enseignants et aux chercheurs.

Keywords: pediatric, emergency medicine, academic, environmental scan, emergency medicine department, major teaching hospitals, fellowships, education, teaching, research, administration, budget, Canada

\section{INTRODUCTION}

Pediatric emergency medicine (PEM) is a relatively new specialty in Canada, first appearing as a Section of the Canadian Paediatric Society in 1986 but was only recognized by the Royal College of Physicians and Surgeons (RCPSC) as a subspecialty of pediatrics and emergency medicine (EM) without certification in 2000 and as a subspecialty with certification in $2006 .{ }^{1}$ The Canadian Association of Emergency Physicians (CAEP) Academic Section was created in 2013 to promote highquality emergency patient care through education and research. Improvements in EM practice benefit all Canadians, whether adult or pediatric patients, as the emergency department (ED) is often the access point to the medical system.

For the young, rapidly growing specialty of PEM, it is essential that resources and infrastructure are available to help academic programs further develop and to prepare our physicians, leaders, researchers, and educators to meet the many challenges of pediatric emergency care. There are not only new diagnostic tools and procedures to incorporate into practice but also pressures including ED crowding and resource limitations. Canadians would benefit from an investigation of current resources allotted to our academic PEM programs, in which young clinicians are trained and new evidence is generated. These programs are integral to improving the pediatric emergency health care of Canadians, who benefit from well-trained physicians, continuing education for these physicians, and high-quality evidence generated by clinician scientists.

There are four major areas of focus to support the mission of university academic departments: administration/leadership, education, research, and funding. The importance of education and its development were addressed at the 2013 CAEP Academic Section Consensus Conference on education scholarship. Recommendations were centred on improvements to teaching and learning, as well as the support and development of education scholars. ${ }^{2-4}$ The follow-up from the 2016 CAEP Academic Symposium on education entitled Emergency Physician Educators of Scholars ... the Path to Success provided recommendations for training career educators, making an impact on education, and having scholarly work published. ${ }^{5-7}$ The variability in infrastructure, support, and productivity for EM research programs across Canada was discussed at the 2014 CAEP Academic Symposium on research, at which recommendations were published to improve research funding, resident research supports, and training for career researchers. ${ }^{8-11}$ Its 2017 follow-up symposium focused on recommendations to improve research through engagement, implementation, and knowledge translation (with published recommendations released in 2018). The 2015 Academic Symposium on leadership provided recommendations for current leaders, regarding leadership strategies, governance, and funding. ${ }^{2-14}$

Although the need for these recommendations is generally accepted among academics, an environmental scan that characterizes each PEM unit in the areas of leadership, administration, education, research, and funding would clearly articulate to the individual sites their specific strengths to build on and weaknesses to address, when comparing themselves to the national averages. Indeed, an environmental scan of (adult) EM academic units was recently published and identified EM academic units without a university status. ${ }^{15,16}$ Key areas of interest from the adult academic environmental scan considered in this pediatric environmental scan included the overarching administration of the academic unit to ensure that there is strength in the EM voice within the university. Funding and access to resources for education and research are necessary to achieve a productive academic unit.

The mission of the CAEP Academic Section is threefold: 1) to improve the emergency care of patients by enhancing academic EM primarily at Canadian medical schools and teaching hospitals; 2) to foster and develop 
education, research, and academic leadership among Canadian emergency physicians, residents, and students; and 3) to provide mentorship in academic EM. Two specific objectives within the terms of reference for the Section are to: 1) create a database of academic activities, physician leaders, infrastructure, and resources at each Canadian medical school; and 2) support academic EDs, divisions, or units at each medical school and teaching hospital to ensure the appropriate status, resources, and infrastructure. To achieve these goals and to assist sites in understanding their local strengths and weaknesses, we conducted an environmental scan of academic PEM activities at all Canadian medical schools and their associated major teaching hospitals.

\section{METHODS}

We developed an 88-item questionnaire (FluidSurveys, Ottawa, ON), focusing on four domains: governance/administration, education, research, and funding (see Supplemental Material). The survey was aligned with a recently published adult academic EM scan questionnaire. ${ }^{15,16}$ It comprised of yes/no and numerical responses, as well as boxes for comments on specific practices or resources available in academic departments. It was pilot tested among members of the CAEP Academic Section Executive,

\begin{tabular}{|c|c|}
\hline & $\begin{array}{l}\text { Number of schools } \\
\text { reporting (\%) }\end{array}$ \\
\hline $\begin{array}{l}\text { Recognition of PEM specialty at your } \\
\text { university }\end{array}$ & $14(100)$ \\
\hline Yes & $11(79)$ \\
\hline No & $3(21)$ \\
\hline Status & $11(79)$ \\
\hline Full department & $0(0)$ \\
\hline Joint department & $0(0)$ \\
\hline Division & $9(64)$ \\
\hline Section & $2(14)$ \\
\hline No status & $3(21)$ \\
\hline \multicolumn{2}{|l|}{ Division/section } \\
\hline Pediatrics* & $10(71)$ \\
\hline EM & $1(7)$ \\
\hline Surgery & $0(0)$ \\
\hline PEM faculty cross-appointed to $\mathrm{EM}^{\dagger}$ & $9(64)$ \\
\hline \multicolumn{2}{|c|}{$\begin{array}{l}\text { EM = emergency medicine; PEM = pediatric emergency medicine. } \\
{ }^{*} \text { One site specified that although they are officially within the pediatrics department, } \\
\text { they have representation within the EM department. } \\
\text { the percentage of faculty with cross-appointments to EM was } 42 \% \text { (ranging from } 5 \% \\
\text { to } 100 \% \text { ). }\end{array}$} \\
\hline
\end{tabular}

including academic department heads, and revised for clarity. The final questionnaire was distributed electronically to the heads (or equivalent) of each PEM unit at the 17 Canadian medical schools.

All data were exported and assessed using a Microsoft Excel $^{\circledR} 2013$ (Microsoft Corp., Redmond, WA) spreadsheet for analysis. Descriptive statistics including proportions, means, medians, and ranges were calculated. The authors (J.A. and I.S.) reviewed all individual site data. Comprehensive individual site-specific tables were created that highlighted missing and internally inconsistent data. Individual site reports were sent by email to their respective respondents, who reviewed the data and provided updated information, as needed. Corrections were made based on the feedback received.

\section{RESULTS}

Three of the 17 medical schools were identified by the survey recipients as having no PEM academic program

\begin{tabular}{|c|c|c|c|c|}
\hline & $\begin{array}{l}\text { Number of } \\
\text { schools } \\
\text { reporting (\%) }\end{array}$ & Mean & Min & Max \\
\hline \multicolumn{5}{|l|}{ Hospitals } \\
\hline $\begin{array}{l}\text { Specialized pediatric } \\
\text { hospital }\end{array}$ & $13(94)$ & & & \\
\hline $\begin{array}{l}\text { Have a separate } \\
\text { specialized pediatric ED }\end{array}$ & $1(7)$ & & & \\
\hline $\begin{array}{l}\text { Pediatric ED takes } \\
\text { residents for rotations }\end{array}$ & $14(100)$ & & & \\
\hline \multicolumn{5}{|l|}{ PEM academic positions } \\
\hline Chair & $10(71)$ & & & \\
\hline Vice-chair & $3(21)$ & & & \\
\hline Dedicated staff for chair & $4(29)$ & & & \\
\hline Number of staff & & 1.9 & 1 & 5 \\
\hline \multicolumn{5}{|l|}{ Faculty physicians } \\
\hline Number $(n=394)$ & $14(100)$ & 28 & 7 & 60 \\
\hline $\begin{array}{l}\text { Primary appointment } \\
\text { to university PEM } \\
\text { division/section }(n=217)\end{array}$ & $11(79)$ & 20 & 2 & 45 \\
\hline Full professors $(n=13)$ & $8(57)$ & 2 & 1 & 2 \\
\hline $\begin{array}{l}\text { Associate professors } \\
\quad(n=64)\end{array}$ & $13(93)$ & 5 & 1 & 18 \\
\hline $\begin{array}{l}\text { Assistant professors } \\
\quad(n=109)\end{array}$ & $13(93)$ & 8 & 1 & 22 \\
\hline Lecturers $(n=103)$ & $5(36)$ & 21 & 1 & 36 \\
\hline $\begin{array}{l}\text { Number with clinical } \\
\text { appointment }(n=105)\end{array}$ & $9(64)$ & 12 & 1 & 24 \\
\hline PhD faculty non-physicians & $1(7)$ & 1 & & \\
\hline
\end{tabular}




\begin{tabular}{|c|c|c|c|c|}
\hline & $\begin{array}{c}\text { Number of } \\
\text { schools reporting } \\
(\%)\end{array}$ & Mean & Min & Max \\
\hline PEM undergraduate clerkship program & $8(57)$ & & & \\
\hline Clerkship director & $8(57)$ & & & \\
\hline Duration of program (weeks)* & $8(57)$ & 2.4 & 2 & 4 \\
\hline Number of students per site & $8(57)$ & 79 & 16 & 150 \\
\hline Provide non-clinical "teaching shifts" & $4(29)$ & & & \\
\hline Provide observerships or electives to pre-clerkship students & $7(50)$ & & & \\
\hline \multicolumn{5}{|l|}{ Resident education } \\
\hline Director of resident education & $10(71)$ & & & \\
\hline $\begin{array}{l}\text { Off-service (non-EM or non-pediatrics) residents that rotate } \\
\text { through annually per site }\end{array}$ & $14(100)$ & 108 & 11 & 260 \\
\hline Provide specific education sessions for off-service residents & $13(93)$ & & & \\
\hline \multicolumn{5}{|l|}{ Fellowship training } \\
\hline PEM fellowship training & $10(71)$ & & & \\
\hline Fellowship director & $10(71)$ & & & \\
\hline Assistant fellowship director & $1(7)$ & & & \\
\hline Staff support (FTEs) for PEM fellowship & $10(71)$ & 0.6 & 0.2 & 1 \\
\hline CARMS fellows per year & $10(71)$ & 1.8 & 1 & 3 \\
\hline Fellows funded from other sources & $5(36)$ & 1.4 & 1 & 2 \\
\hline Advanced PEM fellowship training & $4(29)$ & & & \\
\hline Simulation & $1(7)$ & & & \\
\hline Education & $1(7)$ & & & \\
\hline Trauma & $1(7)$ & & & \\
\hline Ultrasound & $1(7)$ & & & \\
\hline EMS/disaster & $1(7)$ & & & \\
\hline Quality improvement & $0(0)$ & & & \\
\hline Others $^{\dagger}$ & $3(21)$ & & & \\
\hline \multicolumn{5}{|l|}{ Stipends for teaching } \\
\hline Ultrasound & $2(14)$ & 1.5 & 1 & 2 \\
\hline Simulation & $3(21)$ & 1 & 1 & 1 \\
\hline Pediatric Advanced Trauma Simulation Course & $1(7)$ & 1 & 1 & 1 \\
\hline \multicolumn{5}{|l|}{ Education points } \\
\hline Combined education committee for all programs & $9(64)$ & & & \\
\hline Compensation system to reward faculty for teaching activities & $3(21)$ & & & \\
\hline Total amount per year & $3(21)$ & $\$ 206,000$ & $\$ 40,000$ & $\$ 377,000$ \\
\hline
\end{tabular}

and were excluded from further analysis. Of the 14 remaining sites that had academic PEM programs, none had full departmental status at the university. Nine were divisions, two were sections, and three had no status (Table 1), in which the divisions and sections were predominately under the confines of the pediatric departments. Canadian academic PEM is conducted at 13 major teaching hospitals (defined as those that have a full complement of residency programs and a research institute) and one specialized pediatric ED hospital (i.e., a pediatric ED that is not part of a pediatric hospital)
(Table 2). There are 13 full professors, 64 associate professors, and 109 assistant professors of PEM in Canada. In total, there are 394 faculty members if including professors and lecturers, as well as those with clinical appointments. Clerkships are offered at 8 of the 14 universities; all have off-service residents rotate through annually; and fellowship training is offered at 10 of the 14 (Table 3 ).

Continuing professional development (CPD) and education scholarship are two important domains in Canadian academic EM (Table 4). Eight of the 14 sites 


\begin{tabular}{|c|c|c|c|c|}
\hline & $\begin{array}{l}\text { Number of schools } \\
\text { reporting (\%) }\end{array}$ & Mean & Min & Max \\
\hline Education Faculty & $14(100)$ & & & \\
\hline Director of CPD & $7(50)$ & & & \\
\hline \multicolumn{5}{|l|}{ Faculty members with: } \\
\hline Graduate education degrees $(n=18)$ & $7(50)$ & 2.6 & 1 & 6 \\
\hline Formal education fellowships $(n=14)$ & $6(43)$ & 2.3 & 1 & 5 \\
\hline Funding to carry out education scholarship $(n=11)$ & $5(36)$ & 2.2 & 1 & 4 \\
\hline $\begin{array}{l}\text { External peer-reviewed salary awards for educational research/ } \\
\text { scholarship }(n=9)\end{array}$ & $3(21)$ & 3 & 2 & 5 \\
\hline $\begin{array}{l}\text { External peer-reviewed education grants that your group currently } \\
\text { holds }(n=7)\end{array}$ & $3(21)$ & 2.3 & 2 & 3 \\
\hline Number with cross-appointments to EM & $9(64)$ & 7.7 & 2 & 20 \\
\hline Academic education institute/facility with $\mathrm{PhD}$ educators & $7(50)$ & & & \\
\hline Reward faculty for education scholarship, excluding salary awards & $1(7)$ & $\$ 1,000$ & & \\
\hline Provide internal grants & $1(7)$ & $\$ 7,500$ & & \\
\hline \multicolumn{5}{|l|}{$C P D$} \\
\hline Host an annual PEM CPD/CME conference & $8(57)$ & & & \\
\hline Number of days & $8(57)$ & 1.9 & 1 & 3 \\
\hline Registrants last year & $8(57)$ & 130 & 60 & 250 \\
\hline \multicolumn{5}{|l|}{ Workshops or training courses } \\
\hline PALS & $11(79)$ & 4.7 & 2 & 10 \\
\hline APLS & $3(23)$ & 1.3 & 1 & 2 \\
\hline ATLS & $1(7)$ & 1 & & \\
\hline NRP & $0(0)$ & & & \\
\hline Ultrasound & $5(38)$ & 5.2 & 1 & 10 \\
\hline Simulation & $7(54)$ & 6.3 & 1 & 25 \\
\hline Pediatric Advanced Trauma Simulation Course & $1(7)$ & 1 & & \\
\hline CPD/CME outreach workshops for residents on rotations & $10(71)$ & & & \\
\hline CPD/CME outreach lectures/workshops at community hospitals & $10(71)$ & 6.1 & 1 & 15 \\
\hline
\end{tabular}

APLS = advanced pediatric life support; $A T L S=$ advanced trauma life support; $C M E=$ continuing medical education; $C P D=$ continuing professional development; $\mathrm{EM}=$ emergency medicine; $\mathrm{NRP}=$ neonatal resuscitation program; PALS = pediatric advanced life support; $\mathrm{PEM}=$ pediatric emergency medicine.

report hosting an annual CPD conference, and 11 of the 14 have workshops and training courses for their own physicians. Ten of the 14 sites have CPD and continuing medical education outreach workshops for residents on rotation and outreach lectures and workshops at community hospitals. Across Canada, there are 18 PEM faculty members with graduate education degrees and 14 with formal education fellowships, representing 7 of the 14 and 6 of the 14 schools, respectively. Eleven have funding to carry out education scholarship at 5 of the 14 sites, with nine holding external peer-review salary awards for educational research and scholarship.

Research productivity is a key indicator of academic performance, and there are now 31 researchers with salary support based at nine universities (Table 5). Among these, five currently have external peer-reviewed salary awards, and 35 have external peer-review grants, including 18 held by a principle investigator from Canadian Institutes of Health Research or Heart and Stroke Foundation of Canada. Eleven sites have published peer-reviewed papers in the past five years, ranging from 2 to 102 per site. All 14 sites participate in Pediatric Emergency Research Canada (PERC).

Ten sites shared details of their academic funding (Table 6). The annual budgets vary greatly, from $\$ 10,000$ to $\$ 2,607,515$. Sources of funding also vary greatly, with 6 of the 10 reporting university funding, 2 of the 10 reporting hospital funding, 3 of the 10 reporting physicians and practice plans, 4 of the 10 reporting Ministry of Health and Alternate Funding Plans, and 3 of the 10 reporting other sources (including the local EM department, grants, and research institute). 


\begin{tabular}{|c|c|c|c|c|}
\hline & $\begin{array}{l}\text { Number of schools } \\
\text { reporting (\%) }\end{array}$ & Mean & Min & Max \\
\hline \multicolumn{5}{|l|}{ Faculty } \\
\hline Director of research & $11(79)$ & & & \\
\hline Physicians with salary support to conduct research $(n=31)$ & $9(64)$ & 3.4 & 1 & 8 \\
\hline $\begin{array}{l}\text { Funded physicians who completed a research fellowship with MSc/MPH/ } \\
\operatorname{PhD}(n=23)\end{array}$ & $10(71)$ & 2.3 & 1 & 6 \\
\hline $\begin{array}{l}\text { Physician classified as clinician investigators/scientists (>25\% devoted to } \\
\text { research) }(n=18)\end{array}$ & $8(57)$ & 2.3 & 1 & 5 \\
\hline \multicolumn{5}{|l|}{ External research funding } \\
\hline Physicians affiliated with university or hospital research institute & $9(64)$ & & & \\
\hline External peer-reviewed salary grants $(n=5)$ & $4(29)$ & 1.3 & 1 & 2 \\
\hline External peer-reviewed grants currently held by Pls in your group $(n=35)$ & $8(57)$ & 4.4 & 1 & 10 \\
\hline From $\mathrm{CIHR}$ or $\mathrm{HSFC}$ as $\mathrm{PI}(n=18)$ & $6(43)$ & 3.0 & 1 & 5 \\
\hline External peer-reviewed funding held as a PI & $7(50)$ & $\$ 1,865,449$ & $\$ 9,090$ & $\$ 6,000,000$ \\
\hline \multicolumn{5}{|l|}{ Studies } \\
\hline Multicentre trials coordinated $(n=37)$ & $8(57)$ & 5 & 2 & 15 \\
\hline Peer-reviewed studies participating in $(n=77)$ & $11(79)$ & 7 & 1 & 15 \\
\hline Non-education peer-reviewed publications in the past 5 years $(n=423)$ & $11(79)$ & 38 & 2 & 102 \\
\hline Participate in PERC & $14(100)$ & & & \\
\hline PhD biostatisticians & $10(71)$ & & & \\
\hline Database and programming support & $7(50)$ & & & \\
\hline Research nurse and epidemiologist & $2(14)$ & & & \\
\hline \multicolumn{5}{|l|}{ Resources } \\
\hline Full-time non-physician staff for research activities* & $10(71)$ & 2 & 1 & 5 \\
\hline Part-time non-physician staff for research activities* & $5(36)$ & 3 & 1.5 & 4 \\
\hline $\begin{array}{l}\text { Have a compensation or points system to reward faculty for abstracts or } \\
\text { publications }\end{array}$ & $1(7)$ & $\$ 40,000$ & & \\
\hline Provide internal research grants ${ }^{\dagger}$ & $4(31)$ & $\$ 20,333$ & $\$ 1,000$ & $\$ 50,000$ \\
\hline Resident research project facilitator & $10(71)$ & & & \\
\hline Annual summer students & $8(57)$ & 2 & 1 & 5 \\
\hline Research fellowship offered & $3(21)$ & 1.2 & 1 & 1.5 \\
\hline No graduate degree & $2(14)$ & & & \\
\hline MSc & $1(7)$ & & & \\
\hline $\mathrm{MPH}$ & 0 & & & \\
\hline MHSc & 0 & & & \\
\hline $\mathrm{PhD}$ & 0 & & & \\
\hline Research fellows need to complete a thesis & 0 & & & \\
\hline
\end{tabular}

\section{DISCUSSION}

This report is the first comprehensive review of academic PEM activities at Canadian medical schools and major teaching hospitals. It is a follow-up to an academic environmental scan on adult EM published in 2017. ${ }^{15,16} \mathrm{We}$ found that PEM has a presence in patient care and teaching at 14 of the 17 Canadian medical schools. While university status varies across the country, sites are involved in teaching: undergraduate clerkship programs (8), RCPSC residency programs for PEM (10), off-service residents (14), fellowships (10), and CPD (7). Education scholarship is becoming established, with some sites providing salary support for this endeavour. Clinical researchers in PEM have protected time at nine Canadian sites, and some groups have been successful with peer-reviewed funding and publications. Academic activities require funding, and 


\begin{tabular}{|c|c|c|c|c|}
\hline & $\begin{array}{l}\text { Number of schools } \\
\text { reporting (\%) }\end{array}$ & Mean & Min & Max \\
\hline Academic budget for department or division (including education and research) & $10(71)$ & $\$ 759,252$ & $\$ 10,000$ & $\$ 2,607,515$ \\
\hline University & $6(43)$ & $53 \%$ & $17 \%$ & $100 \%$ \\
\hline Hospital & $2(14)$ & $73 \%$ & $63 \%$ & $83 \%$ \\
\hline Physicians/practice plan & $3(21)$ & $72 \%$ & $15 \%$ & $100 \%$ \\
\hline Ministry of Health/Alternate Funding Plan & $4(29)$ & $71 \%$ & $50 \%$ & $100 \%$ \\
\hline Other* & $3(21)$ & $40 \%$ & & \\
\hline \multicolumn{5}{|l|}{ Budget details } \\
\hline Chair/chief $\$^{\dagger}$ & $6(43)$ & $\$ 58,000$ & $\$ 30,000$ & $\$ 90,000$ \\
\hline $\begin{array}{l}\text { Education budget for Department or division (excluding external grants and salary } \\
\text { awards, but including staff, physician stipends, departmental grants, points) }\end{array}$ & $7(50)$ & $\$ 184,667$ & $\$ 10,000$ & $\$ 448,000$ \\
\hline Education and scholarship & $1(7)$ & $\$ 15,000$ & & \\
\hline Undergraduate clerkship ${ }^{\dagger}$ & $5(36)$ & $\$ 13,917$ & $\$ 8,750$ & $\$ 18,000$ \\
\hline Pediatric emergency fellowship ${ }^{\dagger}$ & $8(57)$ & $\$ 34,000$ & $\$ 10,000$ & $\$ 60,000$ \\
\hline Off-service residents ${ }^{\dagger}$ & $5(36)$ & $\$ 26,938$ & $\$ 8,750$ & $\$ 48,000$ \\
\hline Ultrasound $^{\dagger}$ & $3(21)$ & $\$ 36,125$ & $\$ 12,375$ & $\$ 60,000$ \\
\hline Simulation & $4(29)$ & $\$ 40,917$ & $\$ 8,750$ & $\$ 60,000$ \\
\hline Fellowships & 0 & & & \\
\hline $\mathrm{CPD}^{\dagger}$ & $3(21)$ & $\$ 26,188$ & $\$ 4,375$ & $\$ 48,000$ \\
\hline Faculty development & 0 & & & \\
\hline $\begin{array}{l}\text { Department or division (excluding external grants and salary awards but including } \\
\text { staff, physician stipends, departmental grants, and points) }\end{array}$ & $4(29)$ & $\$ 291,875$ & $\$ 42,500$ & $\$ 600,000$ \\
\hline Research director & $5(36)$ & $\$ 27,700$ & $\$ 7,500$ & $\$ 60,000$ \\
\hline
\end{tabular}

there is a greater than 200 -fold range in annual budgets among universities.

Overall, this report has found variability in Canadian academic EM, including sites with resources in areas in which other sites have none. PEM is a relatively new discipline, and its specialty status was recognized in the United States in 1991 and in Canada, the United Kingdom, Australia, and New Zealand nearly a decade later. ${ }^{18}$ Our report shows not only how far Canadian academic PEM has come in less than three decades, from 49 pediatricians practising without formal training in 1989 to nearly 400 subspecialists with academic affiliation in 2017, but also how far it has yet to go to be on equal footing with more traditional specialties such as medicine and surgery. ${ }^{1,17,18}$ There are relatively few full professors of PEM, with some universities having none. While there are teaching activities across Canada, education scholarship and research have much room for growth at many sites, as compared with the highest performing sites in Canada. Three sites do not offer PEM training programs. Our scan identified university governances, with none reporting full departmental status and three reporting no status at all for their program. The appropriate governance structure for a subspecialty is outside the scope of this work. While unclear, data from the United States show that establishment of academic EM departments is strongly associated with many positive academic metrics. ${ }^{19,20}$ The current report will serve as a benchmark against which to judge the future progress of academic EM in Canada. ${ }^{21}$

Moving forward, we anticipate that benchmarks and lessons learned from those sites performing above the national average can be used for direction and goal setting at those sites looking to implement change. Staff members or administrators of each emergency medicine unit could know how it compares to the national average, identify their areas of relative weakness (relative to the national standard), and set priorities for change. In some cases, these data can be used in discussions with university leadership to argue for elevated status, higher budgets, or more teaching and research 
positions. To this end, CAEP has funded consultations for Canadian academic EM units, with expertise provided by the Academic Section in governance funding, education scholarship, and research. Feedback from the consultation visits to adult academic EM units uniformly reflects the positive influence of the guidance provided by the CAEP academic consultation and previous environmental scan. ${ }^{15,16,22}$

Why do our findings matter to Canadian pediatric emergency physicians? PEM, based at the universities and teaching hospitals, has extensive influence on ED care across Canada. The quality of the medical school and postgraduate training influences the careers of pediatric emergency physicians, so offering the best education is of paramount importance. An environmental scan captures the national averages and ranges that, in turn, affords individual sites the ability to assess their commitment to academics and seek additional support.

\section{CONCLUSIONS}

This report provides a comprehensive review of academic activities in PEM across Canada, identifying the variability, benchmarks set by high-performing sites, and opportunities for growth for sites below the national average. By sharing academic practices, CAEP, the Academic Section, and all Canadian PEM academic units will recognize the variabilities; be able to set standards for teachers, educators, and researchers; and, ultimately, improve patient care in our EDs.

Acknowledgements: We particularly thank Angela Marcantonio from the Ottawa Hospital Research Institute and Kelly Wyatt from CAEP. In addition, we are very grateful for the cooperation of EM leaders from each university: British Columbia (Garth Meckler), Alberta (Bruce Wright), Calgary (Angelo Mikrogianakis), Saskatchewan (Vicki Cattell), Manitoba (Scott Sawyer), Western (Rod Lim and Gary Joubert), McMaster (Anthony Crocco), Toronto (Jason Fischer), Ottawa (Gina Neto), McGill (Harley Eisman), Montreal (Antonio D'Angelo), Laval (Mathieu Blanchet and Christian Godin), Dalhousie (Shannon MacPhee), and Memorial (Robert Porter and Kevin Chan).

Competing interests: None declared.

\section{SUPPLEMENTARY MATERIAL}

To view supplementary material for this article, please visit https://doi.org/10.1017/cem.2017.437

\section{REFERENCES}

1. McGillivray D, Jarvis A. A history of paediatric emergency medicine in Canada. Paediatr Child Health 2007; 12(6):453-6.

2. Sherbino J, Van Melle E, Bandiera G, et al. Education scholarship in emergency medicine part 1: innovating and improving teaching and learning. CFEM 2014;16(S1):S1-5.

3. Bhanji F, Cheng A, Frank JR, Snell L, Sherbino J. Education scholarship in emergency medicine part 3: a "how-to" guide. C7EM 2014;16(S1):S13-8.

4. Bandiera G, Leblanc C, Regehr G, et al. Education scholarship in emergency medicine part 2: supporting and developing scholars. C7EM 2014;16(S1):S6-12.

5. Woods RA, Artz JD, Carrière B, et al. CAEP 2016 Academic Symposium on Education Scholarship: Training our future clinician educators in emergency medicine. CFEM 2017;19(S1):S1-8.

6. Chan TM, Thoma B, Hall AK, et al. CAEP 2016 Academic Symposium: "A writer's guide to key steps in producing quality medical education scholarship.”. CFEM 2017;19(S1): S9-15.

7. Frank JR, Cheung WJ, Sherbino J, et al. CAEP 2016 Academic Symposium: "How to have an impact as an emergency medicine educator and scholar." CFEM 2017;19 (S1):S16-21.

8. Perry JJ, Snider CE, Artz JD, et al. CAEP 2014 Academic Symposium: "How to make research succeed in your emergency department: How to develop and train career researchers in emergency medicine." CFEM 2015;17 (3):334-43.

9. Vaillancourt C, Rowe BH, Artz JD, Green R, Émond M, et al. CAEP 2014 Academic Symposium: "How to make research succeed in your department: How to fund your research program.”. CFEM 2015;17(4):453-61.

10. Stiell IG, Artz JD, Perry J, Vaillancourt C, Calder L. Executive summary of the CAEP 2014 Academic Symposium: How to make research succeed in your department. CFEM 2015;17(3):328-3.

11. Calder LA, Abu-Laban RB, Artz JD, et al. CAEP 2014 Academic Symposium: "How to make research succeed in your department: promoting excellence in Canadian emergency medicine resident research.”. CFEM 2015;17 (5):591-9.

12. Petrie D, Chopra A, Chochinov A, et al. CAEP 2015 Academic Symposium: Recommendations for university governance and administration for emergency medicine. CFEM 2016;18(S1):S18-25.

13. Sinclair D, Worthington JR, Joubert G, et al. CAEP 2015 Academic Symposium: Leadership within the emergency medicine academic community and beyond. CFEM 2016;18 (S1):S1-9.

14. Lang ES, Artz JD, Wilkie RD, et al. CAEP 2015 Academic Symposium: Current state and recommendations to achieve adequate and sustainable funding for emergency medicine academic units. CFEM 2016;18(S1): S10-7.

15. Stiell G, Artz JD, Lang ES, et al. An environmental scan of academic emergency medicine at the 17 Canadian medical 
schools: why does this matter to emergency physicians? CORRIGENDUM. CFEM 2017;19(3):247.

16. Stiell IG, Artz JD, Lang ES, et al. An environmental scan of academic emergency medicine at the 17 Canadian medical schools: why does this matter to emergency physicians? C7EM 2017;19(1):39-46.

17. Pena ME, Snyder BL. Pediatric emergency medicine. The history of a growing discipline. Emerg Med Clin North Am 1995;13(2):235-53.

18. Babl FE, Weiner DL, Bhanji F, et al. Advanced training in pediatric emergency medicine in the United States, Canada, United Kingdom, and Australia: an international comparison and resources guide. Ann Emerg Med 2005;45 (3):269-75.
19. Gallagher EJ, Henneman PL. Task force on the development of emergency medicine at academic medical centers. changes in academic attributes associated with establishment of departments of emergency medicine. Acad Emerg Med 1998;5(11):1091-5.

20. Derlet RW. Organization of emergency medicine at medical schools: compelling reasons for departmental status. Acad Emerg Med 2000;7(10):1145-6.

21. Carpenter CR, Cone DC, Sarli CC. Using publication metrics to highlight academic productivity and research impact. Acad Emerg Med 2014;21(10):1160-72.

22. CAEP/ACMU. Academic Section of Emergency Medicine: Consultation Service; 2014. Available at: http://caep.ca/Aca demicSection (accessed July 24, 2017). 